\title{
'Some Are More Equal than Others' \\ Economic Egalitarianism and Welfare Chauvinism in the Netherlands
}

Jeroen van der Waal, Peter Achterberg, Dick Houtman, Willem de Koster \& Katerina Manevska

Forthcoming in Journal of European Social Policy

\begin{abstract}
Various studies have demonstrated that while the lower educated support economic redistribution more than the higher educated do, they nonetheless dislike welfare support for immigrants more strongly. This paper aims to explain this remarkably particularistic application of the principle of economic egalitarianism ('welfare chauvinism') by testing three theories by means of survey data representative for the Dutch population $(\mathrm{N}=1,972)$. The first theory asserts that the low level of political competence of the lower educated is responsible, the second focuses on their weak economic position, and the third claims that their limited amount of cultural capital is decisive. Only the latter explanation is confirmed and implications for debates about ethnocentrism, deservingness and welfare state legitimacy, as well as the ideological profile of the lower-educated working class are discussed.
\end{abstract}

\section{Key words}

Cultural capital, deservingness, ethnic minorities, welfare state, welfare chauvinism 


\section{'Some Are More Equal than Others'}

\section{Economic Egalitarianism and Welfare Chauvinism in the Netherlands}

\section{Introduction}

The so-called 'deservingness' debate about the welfare state addresses the question whether and why the public at large considers particular social groups or categories more or less entitled to welfare (Van Oorschot, 2000). Informed by findings on the United States, where low levels of support for welfare distribution seem to be mainly informed by racial views (Federico, 2005: 684; Gilens, 1995), several studies have demonstrated that in Europe, too, immigrants are considered less entitled to welfare than native needy social categories such as the elderly, the handicapped, or the unemployed (Applebaum, 2002; Bay and Pedersen, 2006; Van Oorschot, 2006; Van Oorschot, 2007; Van Oorschot and Uunk, 2007). Strikingly, this 'welfare chauvinism' (Kitschelt, 1995; Mudde, 2000) is mainly found among the lower educated (Van Oorschot, 2000; Van Oorschot, 2006).

From a classical 'left' versus 'right' perspective this seems paradoxical, because leftism is generally associated with defending the interests of those social categories that find themselves in precarious socio-economic positions. Leftist parties for instance generally strive for policies aimed at economic redistribution, reduction of socio-economic inequality and a more comprehensive welfare state (Budge, 2000). That is why those in precarious socioeconomic positions - lower-skilled workers, those with lower levels of income and the lower educated - generally tend to support these parties (Svallfors, 2007; Achterberg and Houtman, 2009). While these left-wing parties strive for universalist economic redistribution irrespective of ethnicity, that is - their lower-educated native constituencies tend to prefer a 
more particularist type of redistribution, however, and hence combine economic egalitarianism with welfare chauvinism. The aim of this paper is to explain why this is the case, i.e., why the lower educated, in contrast to those higher educated who embrace economic egalitarianism, do not translate the latter into support for welfare distribution to ethnic minorities.

\section{Education, economic egalitarianism, and welfare chauvinism}

Many studies devoted to the ideological outlook of western publics find a bi-dimensional structure of values. One dimension pertains to issues of economic equality, pitting supporters of economic redistribution against supporters of laissez-faire economics. The other dimension concerns issues of social order and cultural diversity, roughly pitting the authoritarian against the libertarian (Converse 1964; Fleishman 1988; Middendorp 1991).

Among the public at large these two value dimensions are hardly related, but educational groups differ on this matter. It is frequently found that the ideological outlook of the higher educated is more one-dimensional than that of the lower educated. The former hence more often coherently combine a progressive (conservative) stance on issues on one dimension with an equally progressive (conservative) stance on issues on the other (see Achterberg and Houtman, 2009; Carmines and Stimson, 1982; Houtman, Achterberg and Derks, 2008). The fact that higher educated advocates of economic redistribution tend to support distribution of welfare to ethnic minorities, whereas the ideological profile of the lower educated on this matter is less one-dimensional, is hence consistent with previous research on ideological structures. An explanation for these differences in dimensionality between the higher and the lower educated still needs to be found, however. 
Three theories might account for the differences between educational categories. The first one revolves around differences in political competence between educational categories (section 2.1), the second concerns economic threat by immigrants (section 2.2), while the third addresses the role of cultural capital.

\subsection{Political competence}

The first theory addresses the role of political competence. Several authors have argued that ideological coherence or dimensionality depends on 'cognitive ability' (Carmines and Stimson 1982; Hyman and Wright, 1979; Lipset, 1981; Jenssen and Engesbak, 1994), 'cognitive sophistication' (Bobo and Licari, 1989), 'political capital' (Bourdieu, 1984), or 'political competence' (Jackson and Marcus, 1975). Despite these different labels, all of these explanations boil down to the idea that the lower educated have less cognitive sophistication than the higher educated, which limits the former in comprehending the complexity of politics. Political ideas are hence assumed to be consistently integrated into a single and logical continuum by well-informed and creative elites (Converse, 1964: 211), because these are equipped with a 'cognitive structure that subsumes content of wide scope and diversity [which is] capped by concepts of a high order of abstraction' (Campbell, Converse, Miller, and Stokes, 1960: 193), allowing them 'to make sense of a broad range of events' (ibid.). The lower educated, on the other hand, are less likely to be equipped to do so, an assumption that has been confirmed by Bourdieu's (1984) finding that the ability to deal with political information (the ability to answer questions about politics rather than selecting the 'don't know' option) increases with education.

What our first theory predicts, in short, is that that high levels of political competence (i.e., the ability to understand and deal with political information) ensures ideological coherence and that this can explain why least ideological coherence tends to be found among 
the lower educated (Fiske and Kinder, 1981; Judd and Krosnick, 1989; Lerner, Nagai and Rothman, 1991; Zaller, 1992). If this is indeed the case, the lower educated translate their economic egalitarianism into welfare chauvinism because of their limited political competence (hypothesis 1).

\subsection{Ethnic competition}

The support for economic egalitarianism among the lower educated can of course be explained by the theoretical rationale of class analysis. According to class theory, support for redistribution of wealth and income is a direct reflection of class-based economic interests (Clark, 1996; Lipset, 1981). Research has demonstrated time and again that it is the weak economic position of the lower educated that drives their support for egalitarian measures (De Witte, 1997; Houtman, 2001, 2003; Marshall et al., 1988; Svallfors, 1991; Wright, 1985; Van der Waal et al., 2007), and makes left-wing parties their 'natural' allies because these represent their class interests (e.g., Alford, 1967; Clark and Lipset, 1991). However, according to the so-called 'ethnic competition theory', these class interests tied to an economically insecure position are not universal, but conditional on the ethnic group to which one belongs.

While the theory discussed above assumes that the lower educated lack the cognitive sophistication that is required to comprehend the complexity of politics, the ethnic competition theory rests upon an opposite assumption: it assumes that lower-educated natives have enough insight into the complexity of politics to understand that immigration puts pressure onto welfare state programmes and as such poses a threat to their own economic security. The ethnic competition theory proposes that it is precisely because of this insight that lower-educated natives adopt a negative stance towards ethnic minorities in order to protect the economic interests of the native ethnic in-group. The core idea of the ethnic competition 
theory is hence that 'competition for resources leads to attempts at exclusion of one group by another' (Olzak, 1992: 163). This competition, of course, is most severe for people holding economic positions similar to those of ethnic minorities. As most ethnic minorities in western societies hold weak to very weak economic positions (Coenders, 2001; Scheepers et al., 2002), it is primarily the lower-educated natives with whom they compete over scarce resources. Consequently, according to the ethnic competition theory, these lower-educated natives will adopt a negative stance towards ethnic minorities in order to protect their own, or their own group's position.

As welfare arrangements are scarce economic resources, especially for the economically weak whose economic misfortunes these arrangements intend to abate, the ethnic competition theory could explain why lower-educated natives consider ethnic minorities less entitled to welfare. This logic has been put forward by Kitschelt (1995) who suggested that workers are welfare chauvinists because 'they fear their material well-being may deteriorate if a welfare state backlash occurs [due to immigration]' (Kitschelt, 1995: 263).

Contrary to conventional (Marxist) class analysis, then, the ethnic competition theory assumes that class interests are defined in an ethnically particularistic manner and hence as shared only with those who belong to the same ethnic group. The ethnic competition theory thus predicts that the lower educated translate their economic egalitarianism into welfare chauvinism because of their weak economic position (hypothesis 2).

\subsection{Cultural capital}

The third theory does not revolve around economic conditions and interests, but around differences in cultural capital. It has often been found that the lower educated are less tolerant towards cultural differences and hence more intolerant towards out-groups than the higher 
educated (Emler and Frazer, 1999; Stubager, 2008, 2009). It is important to emphasize that this intolerance of the less educated does not stem from their weak economic position, but is firmly rooted in their limited amount of cultural capital (Achterberg and Houtman, 2006; Houtman, 2003; Van der Waal, 2010), i.e., the ability to recognize cultural expressions and comprehend their meaning. Those with ample cultural capital, on the other hand, are much more progressive when it comes to issues concerning cultural diversity (Achterberg and Houtman 2009; Lamont 1987). While the higher educated tend to appreciate that 'each society, with its norms and values, is one of many, capable of change - in various directions and is the product of man's effort to come to terms with the world around him and with the needs of an ongoing social order' (Gabennesch 1972: 859), the lower educated are 'more likely to view the social world in fixed, absolute terms' so as to embrace a "reified" view of social reality' (Idem: 862-3).

Cultural capital hence stimulates a 'denaturalization of culture' in that it spawns an understanding of culture as humanly constructed and as such ultimately contingent and radically different from the givens of nature. Research has pointed out that this applies as much to 'embodied' cultural capital (high-status cultural participation and consumption) as to 'institutionalized' cultural capital (education) in the sense of Bourdieu (1986), while income proves not at all to affect authoritarianism and intolerance, underscoring that education indeed plays a role here as an indicator for cultural capital rather than economic position (Houtman, 2003; Houtman, Achterberg and Derks, 2008).

This 'liberalizing' role of cultural capital is a cultural peculiarity of modern liberal democracies, as the negative relationship between education on the one hand and ethnic intolerance and authoritarianism on the other is substantially weaker or even completely absent in less modern, less liberal and less democratic societies (Farnen and Meloen, 2000; Simpson, 1972; Weil, 1985). The same goes for art, which in less modern, less liberal and less 
democratic societies tends to reproduce and legitimate the established order - think of medieval art, which was mostly religiously inspired and as such reaffirmed and legitimated the by then dominant Christian worldview (Wilson, 1982), or think of Nazi suspicions of 'entartete' modern avant-garde art -, while in the contemporary western world art is rather aimed at 'denaturalization', i.e., the critical interrogation, deconstruction and disturbance of established cultural meanings and practices, aimed at exposing their contingency, social constructedness and hence 'unnaturalness' (Bell, 1976; Jensen, 1995).

The 'liberalizing' role of cultural capital in liberal democracies assumes that particularly those with limited amounts of cultural capital experience cultural diversity as a threat, triggering feelings of distrust and cultural insecurity in them. Indeed, research has pointed out that those with less education are more culturally insecure (Elchardus and Smits, 2002, McDill, 1961) and that it is indeed this cultural insecurity that gives rise to their authoritarianism and intolerance (Achterberg and Houtman, 2009; Blank, 2003; Derks, 2006; Eisinga and Scheepers, 1989; Elchardus and Smits, 2002; Lutterman and Middleton, 1970; McDill, 1961; Roberts and Rokeach, 1956; Srole 1956).

According to this third theory, then, lower-educated natives are economic egalitarian because of their weak economic position, but are also welfare chauvinists because of their limited amount of cultural capital and the cultural insecurity this gives rise to, i.e., because they understand immigrants as a cultural instead rather than an economic threat. We hence hypothesize that the less educated translate their economic egalitarianism into welfare chauvinism because of their limited amount of cultural capital and the cultural insecurity this entails (hypothesis 3). 


\section{Data and measurement}

\subsection{Data}

In order to test the hypotheses proposed above, we used data that were collected in the Netherlands in 2006. The data have been collected by CentERdata and are representative for the Dutch population.[1] A total of 2,682 individuals were contacted to participate in the study, of whom 1,972 actually completed the questionnaire - yielding a response rate of 73 percent. A comparison with official statistics from Statistics Netherlands (CBS) showed that the elderly, higher income categories, and the higher educated are somewhat overrepresented. We corrected for these overrepresentations by applying a weighting factor.

\subsection{Measurement}

For our measurement of economic anti-egalitarianism / egalitarianism we asked respondents to what extent they agreed with five Likert-type items with response categories ranging from 'totally disagree' (1) to 'totally agree' (5) - the 'don't know' answers were treated as missing:

1. The state should raise social benefits.

2. There is no longer any real poverty in the Netherlands.[2]

3. Large income differences are unfair because everyone is essentially equal.

4. The state should intervene to reduce income differences.

5. Companies should be obliged to allow their employees to share in the profits.

Factor analysis on the responses on these items yielded one factor with an eigenvalue of 2.69, explaining about $54 \%$ of the variance within these items. After standardizing the items we constructed a scale by calculating the mean score for those respondents who validly responded to at least four of the five items (Cronbach's alpha=0.78). Higher scores on the scale stand for more economic egalitarianism. 
Welfare chauvinism / universalism concerns a meta-scale created out of three subscales concerning the distribution of welfare support to ethnic minorities. The first subscale, ethnic redistribution, is measured with four items concerning support for distributing scarce economic resources to ethnic minorities. The response categories of these items range from 'totally agree' (1) to 'totally disagree' (5) - the 'don't know' answers are treated as missing.

1. In the future, non-western immigrants should have fewer entitlements to social assistance than Dutch natives.

2. In the future, western immigrants should have fewer entitlements to social assistance than Dutch natives.

3. In the future, economic refugees should have fewer entitlements to social assistance than Dutch natives.

4. In the future, political refugees should have fewer entitlements to social assistance than Dutch natives.

Factor analysis on these items yielded one factor with an eigenvalue of 3.25, which explains about $81 \%$ of their variance. After standardizing the items we constructed a scale by calculating the mean for each respondent with valid scores on at least three of the four items. Higher scores on the scale stand for more support for economic redistribution to ethnic minorities (Cronbach's alpha $=0.92)$.

The second subscale, ethnic deservingness, is measured with items on the degree to which respondents perceive ethnic minorities as deserving social assistance. We asked the respondents to indicate, on a scale from 1) 'absolutely undeserving' to 10) 'absolutely deserving', whether they think that the following social categories are entitled to financial support by society: 1) Asylum seekers; 2) Illegal aliens; 3) Ethnic minorities. Factor analysis on the responses on these three items yielded one factor with an eigenvalue of 2.10, explaining about $70 \%$ of the variance within these items. After standardizing the items a scale 
was made by calculating the mean scores for respondents who had valid scores on all three items (Cronbach's alpha $=0.78)$. Higher scores on the scale indicate that respondents perceive ethnic minorities as more deserving.

Ethnic anxiety is the third subscale and measures the fear that immigration harms the economic position of natives. For this scale we used the following four items with response categories ranging from 'totally disagree' (1) to 'totally agree' (5) - the 'don't know' answers are treated as missing:

1. Average wages and salaries are generally brought down by people coming to live and work here.

2. People who come to live and work here generally harm the economic prospects of the poor more than the rich.

3. If people who come to live and work here are unemployed for a long period, they should be made to leave.

4. People who have come to live here should be given the same rights as everyone else.[3]

Factor analysis on the four items for ethnic anxiety yielded one factor with an eigenvalue of 2.10, explaining about $53 \%$ of their variance. The fourth item is recoded and all items are standardized before constructing a scale by calculating the mean for respondents who had valid scores on at least three of the four items (Cronbach's alpha $=0.70)$. Higher scores on the scale stand for more fear that immigration harms the economic position of natives.

To determine whether the items of economic anti-egalitarianism / egalitarianism tap into another ideological dimension than the ones of ethnic redistribution, ethnic deservingness and ethnic anxiety we executed two factor analyses. The first allowed for just one factor, the second one allowed for two factors. The first (one-factor) model in table 1 shows that the subscales ethnic redistribution, ethnic deservingness and ethnic anxiety cluster together into a 
overarching dimension of welfare chauvinism / universalism that only partially overlaps with economic anti-egalitarianism / egalitarianism (as indicated by economic egalitarianism's low factor loading of 0.31 in the one-dimensional solution).

Table 1 Secondary factor analysis on scales for economic egalitarianism and welfare universalism (Varimax rotation for the two-dimensional model; $\mathrm{N}=1,629$ )

One-dimensional model

Two-dimensional model

Factor $1 \quad$ Factor $1 \quad$ Factor 2

\begin{tabular}{lccc}
\hline Economic egalitarianism & 0.31 & 0.08 & 0.99 \\
Ethnic redistribution & 0.85 & 0.86 & 0.08 \\
Ethnic deservingness & 0.85 & 0.82 & 0.22 \\
Ethnic anxiety & -0.80 & -0.84 & 0.06 \\
Eigenvalue & 2.19 & 2.12 & 1.03 \\
$\mathrm{R}^{2}$ & 0.55 & 0.53 & 0.25 \\
\hline
\end{tabular}

Allowing for two factors in the second model shows that there are indeed two separate dimensions, the first explaining support for welfare assistance to ethnic minorities and the latter explaining economic egalitarianism. After recoding the subscale ethnic anxiety and standardizing ethnic redistribution, ethnic deservingness and ethnic anxiety we constructed a meta-scale welfare chauvinism / universalism by calculating the mean score for respondents on these three subscales. Higher scores on this scale stand for more support to distribute welfare to ethnic minorities.

Education was measured by using the highest level of education respondents attained. For the first part of our analyses, respondents have been recoded into three educational categories of roughly comparable size: low (only primary education and VMBO, N=704), medium (HAVO/VWO/MBO, N=639) and high (College/Academic, N=771). For our multiple linear regression analyses, education was coded as the number of years of schooling 
needed for the highest level of education a respondent attained, yielding a variable ranging from 8 to 18 years.

To measure political competence we used the thirteen items for economic antiegalitarianism / egalitarianism and welfare chauvinism / universalism.[9] Following Bourdieu (1984: 426-432; see also Achterberg and Houtman, 2009), we measure political competence as the ability to answer items pertaining to political issues. As public opinion research has shown, people indicating not to know the answer to a Likert-type item do not know how to consistently motivate a conclusion about these issues based on their set of norms and predispositions (Nisbet, 2005, Zaller, 1992: 6). Those respondents indicating that they are unable to formulate an opinion hence lack the political competence to frame political issues into a meaningful opinion saying they (fully) agree, (fully) disagree, or are somewhere in between (see also Carmines and Stimson 1982). Therefore we recoded our Likert-type items in such a way that respondents who gave a valid response were coded as 1 , and those who opted for the 'don't know' answer were coded as 0 . Factor analysis showed that all items load strongly on the first factor with an eigenvalue of 6.49 that explained 50 percent of the variance within all items. We constructed a scale for political competence running from zero (for those who were unable to answer all thirteen questions) to thirteen for those who responded validly to all thirteen questions (Cronbach's $\alpha=0.91$ ). Although it is constructed using the items for economic anti-egalitarianism / egalitarianism and welfare chauvinism / universalism, the scale for political competence does not correlate with either of these two scales (-0.04 and 0.03 respectively, both $p>0.05)$. As one would expect, our measure of political competence is positively associated to the level of education: the higher educated are better able to formulate valid responses to these items and as such have higher levels of political competence than the lower educated (Pearson's $r=0.20, p<0.01$ ). 
Economic position was measured as in Achterberg and Houtman (2009) using three separate indicators. Firstly, respondents were asked whether or not they were unemployed at the moment of the interview ('not unemployed' (1); 'underemployed' (2); 'totally unemployed' (3)). Secondly, respondents were asked into which of four categories their monthly net household income fell: 1$) € 2,601$ or more; 2$) € 1,801$ to $€ 2,600 ; 3) € 1,151$ to $€$ $1,800$; and 4$) € 1,150$ or less (income). Finally, we measured the current welfare dependency of our respondents by asking whether or not they were receiving the following welfare benefits: 1) unemployment benefits; 2) incapacity benefits; 3) sickness benefits; 4) social assistance. Each item could be answered with yes (1) or no (0). Respondents dependent on one or more of these four welfare arrangements were coded as 1 , others were coded as 0 .

Drawing on Bourdieu (1986), we use cultural participation as a measure of cultural capital, which is common practice (Achterberg, 2006a; 2006b; Achterberg \& Houtman, 2006; DiMaggio, 1982; DiMaggio and Mohr, 1985; Dumais, 2002; Eitle and Eitle, 2002; Houtman, 2001; 2003; Houtman, Achterberg and Derks, 2008, Katsillis and Rubinson, 1990; Van der Waal, 2010). Cultural participation was measured by asking each respondent the number of books he or she owned,[4] the number of novels he or she had read in the previous three months, the number of times he or she had been to concerts, the theatre, cabaret or ballet and art exhibitions,[5] the frequency with which he or she speaks with others about art and culture,[6] and the extent to which he or she regards him- or herself as 'a lover of arts and culture'.[7] Factor analysis produced one factor with an eigenvalue of 2.66, which explains about 53 percent of variance within all five items. The reliability of the scale consisting of the standardized items is 0.77 , and higher scores indicate higher levels of cultural participation.

Cultural insecurity was measured by means of a slightly altered version of Srole's (1956) widely used scale.[8] We used four items, with response categories ranging from 'totally disagree' (1) to 'totally agree' (5) - the 'don't know' answers are treated as missing: 
1. These days a person doesn't really know whom he can count on.

2. Nowadays a person has to live pretty much for today and let tomorrow take care of itself.

3. In spite of what some people say, the lot of the average man is getting worse, not better.

4. It's hardly fair to bring children into the world, the way things look for the future. Factor analysis of the responses to these four items yielded a first factor with an eigenvalue of 2.17, explaining 54 percent of the common variance. We have constructed the scale for cultural insecurity by standardizing and summing the items with higher scores indicating more cultural insecurity (Cronbach's $\alpha=0.71$ ).

\section{Results}

\subsection{Economic egalitarianism and welfare chauvinism}

Although economic anti-egalitarianism / egalitarianism and welfare chauvinism / universalism both concern issues of economic redistribution, the factor analyses already demonstrated that they concern two dimensions that largely operate independent from one another. The zero-order correlation of merely $0.17(\mathrm{p}<0.01)$ between the two dimensions points in the same direction.

Figure 1 shows furthermore that the relationship between support for economic egalitarianism and welfare chauvinism differs between educational categories. We found the strongest correlation between economic anti-egalitarianism / egalitarianism and welfare chauvinism / universalism for the higher educated and the weakest for the lower educated. This means that the higher educated strongly combine economic egalitarianism with support for welfare assistance to ethnic minorities (and economic anti-egalitarianism with low support for welfare assistance to ethnic minorities). As expected, this relationship decreases steadily 
with a declining educational level. For the lowest educational category, we still find a statistically significant and positive effect, but compared to the findings for the higher educated this relationship is rather weak. For the lower educated, being economic egalitarian implies support for welfare assistance to ethnic minorities to a much lesser extent than for the higher educated. Thus, the ideological profile of the lower educated is less one-dimensional, just like we expected.

Figure 1 Associations between economic egalitarianism and welfare universalism for three educational categories

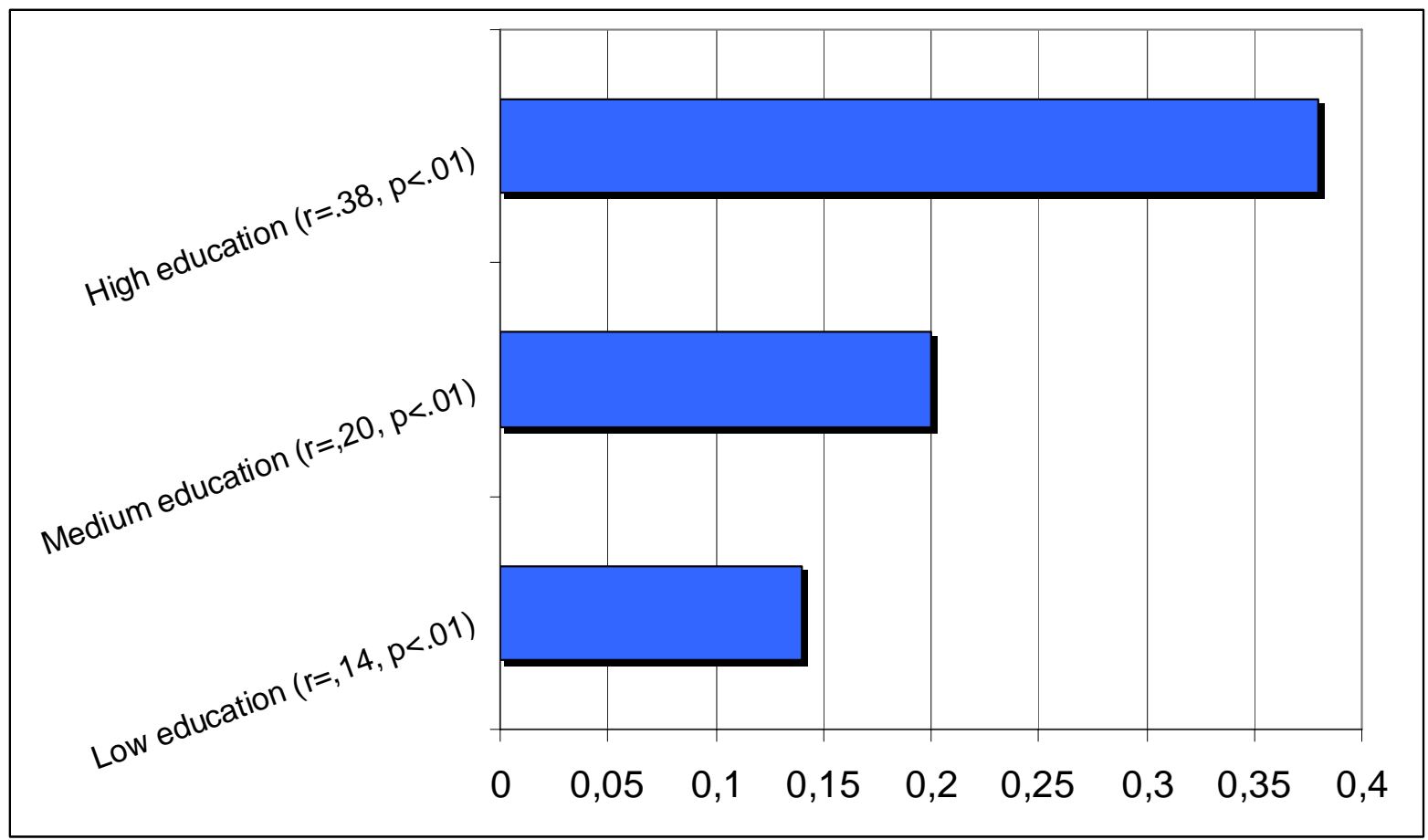

In table 2 we test whether the findings that are depicted in figure 1 are statistically significant. The positive and statistically significant effect of the interaction term of education and economic anti-egalitarianism / egalitarianism shows they are: the association between economic anti-egalitarianism / egalitarianism and welfare chauvinism / universalism clearly increases as people have a higher level of education. The question is how this pattern can be explained. 

economic egalitarianism and welfare universalism on educational level (Linear regression, Method=Enter; entries are beta's)

\begin{tabular}{lc}
\hline & Model 1 \\
\hline Education & $0.25^{* *}$ \\
Economic egalitarianism & $0.05 \mathrm{~ns}$ \\
Education * Economic egalitarianism & $0.17^{* *}$ \\
\hline Rsq (adjusted) & 0.09 \\
$\mathrm{~N}$ & 1,628 \\
\hline$* * 0<0.01(t w 0-28 i l e d$ test for significance)
\end{tabular}

$* * \mathrm{p}<0.01$ (two-tailed test for significance)

4.2. Why is the association between egalitarianism and welfare universalism conditional on level of education?

Before investigating how it can be explained that the combination of economic egalitarianism and welfare chauvinism differs between educational categories, we first show the driving forces of both dimensions in table 3. It shows that political competence underlies neither economic egalitarianism nor support for welfare assistance to ethnic minorities. Moreover, it demonstrates that an economically insecure position leads to economic egalitarianism, whereas it does not influence welfare universalism. The lower educated, the unemployed, those with low incomes and those who are dependent on welfare are the greatest supporters of economic redistribution by the state, but they do not differ from those in stronger economic positions regarding support for distribution of welfare to ethnic minorities. The indicators for cultural position - cultural participation and cultural insecurity - show an opposite pattern: their influence on welfare universalism is much stronger than their effect on economic egalitarianism. Together, these findings demonstrate that welfare chauvinism / universalism has cultural roots - welfare universalism can be found among people with lower levels of 
cultural insecurity and higher levels of cultural participation, while a weak economic position does not have any effect on welfare universalism whatsoever.[10]

Table 3 Drivers of economic egalitarianism and welfare universalism (Linear regression, method= enter; entries are beta's)

Economic egalitarianism Welfare universalism

\begin{tabular}{lll}
\hline Political competence & $-0.03 \mathrm{~ns}$ & $0.01 \mathrm{~ns}$ \\
Education & $-0.15^{* *}$ & $0.05 \mathrm{~ns}$ \\
Unemployed & $0.07^{* *}$ & $0.03 \mathrm{~ns}$ \\
Low income & $0.13^{* *}$ & $0.03 \mathrm{~ns}$ \\
Welfare dependency & $0.12^{* *}$ & $0.04 \mathrm{~ns}$ \\
Cultural participation & $-0.05^{*}$ & $0.26^{* *}$ \\
Cultural insecurity & $0.09^{* *}$ & $-0.31^{* *}$ \\
\hline Rsq (adjusted) & 0.10 & 0.22 \\
$\mathrm{~N}$ & 1,818 & 1,644 \\
\hline
\end{tabular}

$* \mathrm{p}<0.05 ; * * \mathrm{p}<0.01$

These preliminary results already cast doubts on the empirical validity of the political competence theory and ethnic competition theory for explaining differences in combinations of economic egalitarianism and welfare chauvinism between educational categories. Instead, they point in the direction of the cultural logic that focuses on the low levels of cultural capital and high levels of cultural insecurity of the lower educated as compared to the higher educated. The decisive test is given in table 4 .

Model 1 replicates the results of table 2 by showing that the higher educated more often combine their economic egalitarian values with support for distributing welfare to ethnic minorities than the lower educated. The subsequent models 2,3 , and 4, test the hypotheses derived from the political competence theory, ethnic competition theory and the theory 
concerning the cultural logic respectively. If the interaction-effect of education and economic anti-egalitarianism / egalitarianism is reduced, we find the reason why lower-educated natives more often combine economic egalitarianism with welfare chauvinism than the higher educated.

Table 4 The conditionality of the association between economic egalitarianism and welfare universalism on educational level explained (Dependent variable welfare universalism; Linear regression, method=enter; entries are beta's)

\begin{tabular}{lcccc}
\hline & Model 1 & Model 2 & Model 3 & Model 4 \\
\hline Education & $0.25^{* *}$ & $0.25^{* *}$ & $0.23^{* *}$ & $0.15^{* *}$ \\
Economic egalitarianism & $0.05 \mathrm{~ns}$ & $0.05 \mathrm{~ns}$ & $0.06 \mathrm{~ns}$ & $0.20^{* *}$ \\
Education * Economic egalitarianism & $0.17^{* *}$ & $0.16^{* *}$ & $0.17^{* *}$ & $0.08^{*}$ \\
Political competence & -- & $-0.01 \mathrm{~ns}$ & $-0.01 \mathrm{~ns}$ & $0.01 \mathrm{~ns}$ \\
Unemployed & -- & -- & $0.02 \mathrm{~ns}$ & $0.02 \mathrm{~ns}$ \\
Low income & -- & -- & $-0.07^{* *}$ & $-0.06^{*}$ \\
Welfare dependency & -- & -- & $-0.01 \mathrm{~ns}$ & $0.02 \mathrm{~ns}$ \\
Cultural participation & -- & -- & -- & $0.24^{* *}$ \\
Cultural insecurity & -- & -- & -- & $-0.33^{* *}$ \\
\hline Rsq (adjusted) & 0.09 & 0.09 & 0.09 & 0.26 \\
$\mathrm{~N}$ & 1,628 & & & \\
\hline
\end{tabular}

Political competence was entered in model 2 to tests the explanation that addresses the importance of this competence. As can be seen from the model, it does not yield a significant effect. Therefore, it cannot explain why the association between economic egalitarianism and welfare universalism is higher among the higher educated than among the lower educated. Although the zero-order correlation between educational level and political competence is positive and statistically significant (Pearson's $r=0.20, p<0.01$ ), the higher political 
competence of the higher educated clearly does not drive the pattern observed. The interaction-effect found in model 1 remains intact, which leads us to reject our first hypothesis.

The three indicators for weak economic position were entered into the third model to test the explanatory mechanism centered on competition concerning scarce resources between ethnic groups. It appears that neither the unemployed nor those dependent on welfare (two largely overlapping economically insecure social categories) differ from the employed and those not dependent on welfare respectively when it comes to support for welfare assistance to ethnic competitors. Only one indicator for a weak economic position, low income, has a significant effect, which means that people with lower levels of income are less supportive of welfare assistance to ethnic minorities. Although this is in accordance with the ethnic competition theory, it cannot explain why the lower educated combine economic egalitarianism with welfare universalism to a lesser extent than the higher educated: the interaction-effect found in model 1 does not decline in strength. Hence, the results in this model lead us to reject the second hypothesis.

Finally, the last model tests the explanation based on the aversion to cultural differences due to low levels of cultural capital and high levels of cultural insecurity. As can be seen from model 4 we find that a higher score on cultural insecurity is negatively associated to welfare universalism and a high score on cultural participation is positively associated with welfare universalism. Both effects were expected according to the cultural logic addressed in section 2.3, and suggest that cultural differences drive the resistance to support welfare assistance to ethnic minorities. And indeed, the magnitude of the interaction effect between education and economic egalitarianism reduces strongly, from 0.17 to 0.08 , after entering cultural participation and cultural insecurity. It is the cultural insecurity (Pearson's $r$ between education and cultural insecurity is $-0.24 ; p<0.01$ ) and low level of 
cultural participation (Pearson's $r$ between cultural participation and educational level is 0.22 ; $p<0.01$ ), of the lower educated that underlies their welfare chauvinism. Contrary to their support for economic egalitarianism, which is informed by economic interests such as a lower income and welfare dependency, the welfare chauvinism of the lower educated is rooted in their cultural position. The analyses performed above hence indicate that the lower educated are simultaneously inclined to support economic egalitarianism for economic reasons and inclined to reject welfare universalism for cultural reasons. The strong reduction in the magnitude of the interaction-term thus means that our third hypothesis can be confirmed: the lower educated translate their economic egalitarianism into welfare chauvinism because of their limited amount of cultural capital and the cultural insecurity this entails.

After modeling cultural capital and cultural insecurity there proves to be an association between economic anti-egalitarianism / egalitarianism and welfare chauvinism / universalism. In model 1 through 3 this association was suppressed, which can be explained according to the cultural logic as well. After entering cultural participation and cultural insecurity the cultural conservatism that underlies particularistic economic egalitarianism, especially among lower-educated natives, is filtered out. It is this cultural conservatism of the 'natural' social basis of left-wing parties that causes their opinions on cultural matters to diverge from left-wing elites. Once controlled for this cultural conservatism, the economic egalitarianism of the lower educated becomes more universal, and consequently includes support for distributing welfare to ethnic minorities.

\section{Conclusions}

Several studies on deservingness in European countries found that although lower-educated natives strongly support economic egalitarianism they consider ethnic minorities least entitled 
for welfare arrangements. From a classical leftist politics point of view this seems rather odd, as ethnic minorities belong to the weakest economic categories in these countries, and lowereducated natives support leftist parties for their politics of economic redistribution. Although leftist parties strive for universal redistribution from the rich to the poor, i.e. irrespective of the ethnicity of the latter, their native social basis apparently has a more particularistic conception of economic redistribution: primarily the economically weak of the same ethnicity are considered entitled to welfare.

This ideological profile of a 'progressive' stance concerning economic redistribution and a 'conservative' stance on the distribution of welfare to ethnic minorities calls for an explanation, and the central aim of this article was to find it. Therefore, we assessed three competing theories that could account for the observation that the lower educated are more likely to combine economic egalitarianism and welfare chauvinism. The first one concerned the idea that the lower educated are less politically competent, the second one revolves around competition for scarce economic resources between ethnic groups, and the third one emphasized cultural capital.

Although the lower educated are less politically competent than the higher educated, this could not account for their combination of economic egalitarianism and low support for the distribution of welfare to ethnic minorities. The ethnic competition theory could not explain this combination either. Despite that the lower-educated Dutch experience competition from immigrants due to their weak economic position (Van der Waal, 2009a, Van der Waal, 2009b), this proved not to be responsible for their reluctance to distribute welfare to ethnic minorities. What is responsible, is lower-educated natives' limited amount of cultural capital and high level of cultural insecurity. This accounts for the fact that they more often support welfare chauvinism irrespective of their economic egalitarianism. 
This finding shows that only on the basis of their weak economic position the lower educated are the 'natural' social basis of leftist parties. This weak economic position is what drives their economic egalitarianism and subsequent support of leftist policies aimed at distribution of wealth from the rich to the poor. A low level of education does not only indicate a weak economic position however, but also a low level of cultural capital and is strongly associated with high levels of cultural insecurity. The latter two both yield an aversion to cultural differences which drives the opinion of the lower-educated natives that some are more equal than others. As ethnic minorities are culturally different, lower-educated natives consider them as less entitled to welfare than the economically weak of their own ethnicity. Higher-educated natives, on the other hand, hold less ethnocentric views when it comes to the distribution of welfare. If they are economic egalitarian, it is economic egalitarianism of a more universal kind due to their large amount of cultural capital and high level of cultural security.

These finding are at odds with the argument of Kitschelt (1995: 262) that 'the derivative of the comprehensive welfare state is thus a "welfare chauvinism" that is not necessarily rooted in cultural patterns of xenophobia and racism, but in a "rational" consideration of alternative options to preserve social club goods in efficient ways'. If so, the welfare chauvinism of lower-educated natives would be driven by their weak economic position and not by their limited amount of cultural capital and the cultural insecurity this entails. However, our study clearly shows the opposite: a weak economic position has no impact on welfare chauvinism whatsoever, while a weak cultural position does, and quite strongly so.

The findings in this article have implications for two adjacent fields of research, the first one being the debate on the impact of immigration on support for the welfare state. Mau and Burckhardt (2009) recently found that the impact of immigration on the overall opinion 
towards granting rights to immigrants in Western Europe is rather small. Consequently, they conclude that 'the fear that the welfare state might lose its support when the share of migrants increases seems to be exaggerated' (Mau and Burckhardt, 2009: 225). The findings in this study suggest that this conclusion is premature as the impact of immigration on the overall opinion might be small, but that this is the case because it mainly affects the lower educated. For the question as to whether immigration undermines support for the welfare state this is a highly salient finding, as the lower educated form the 'natural' basis of left-wing parties and associated welfare state arrangements. In short, immigration might have a small effect on opinions concerning the welfare state in general, but affects the opinions of the 'natural' supporters of that welfare state the most. The eventual consequences of immigration on support for the welfare state might therefore be stronger than Mau and Burckhardt (2009) suspect.

This brings us to the second debate that can be informed by our findings. Several studies have shown that cultural issues have risen in salience in the political domain of western countries in recent decades (Inglehart, 1997; Hechter, 2004; Achterberg, 2006b, De Koster et al., 2008; Van der Waal and Achterberg, 2006b). Consequently, besides the electoral cleavage between the working class (left-wing parties) and the middle class (rightwing parties) driven by their class interests, a new cleavage arose that revolves around questions of social order and cultural identities (Achterberg, 2006b; Hechter 2004). This new cleavage does not so much pit the economically weak against the economically strong (the socalled democratic class struggle), but the culturally conservatives or authoritarians versus the culturally progressives or libertarians as united in new-rightist and new-leftist parties respectively. The existence of an economic and cultural cleavage in the political domain in western countries yields a cross pressure in the electorate (Achterberg and Houtman, 2006; Houtman, 2003). On the basis of their class interests the lower educated are inclined to vote 
for left-wing parties, while on the basis of their cultural conservatism or authoritarianism they are inclined to vote for new-rightist parties (Van der Waal et al., 2007; Houtman et al., 2008). This cross-pressure has seriously undermined the social bases of classical social democratic parties in Western Europe (Achterberg, 2006b; Van der Waal et al., 2007).

The findings in this article indicate that it is not only the rising salience of cultural issues in these countries that is responsible for this, but also the fact that the welfare state in its current form is discredited (e.g., Houtman, Achterberg and Derks, 2008). This is not very likely to change due to its intrinsic universal nature - no ethnic groups are excluded from welfare arrangements. Consequently, one of the classical instruments of left-wing parties to persuade lower-educated natives to vote for them - welfare arrangements to abate their economic misfortunes - can also lead to an even stronger alienation than already has occurred in recent decades due to the rising salience of cultural issues in the political domain. The universal nature of the welfare state combined with immigration is just as likely to commit lower-educated natives to new-rightist parties because of their cultural conservatism or authoritarianism. 


\section{Notes}

[1] For more information see: http://www.centerdata.nl/en/index.html.

[2] The responses to this item have been recoded to match the direction of the other items: higher scores stand for more economic egalitarianism.

[3] The responses to this item have been recoded to match the direction of the other items: higher scores stand for more ethnic anxiety.

[4] Answer categories ranged from 1: 'less than 50' to 6: ' 1,000 or more'.

[5] Answer categories ranged from 1: '(almost) never' to 4: 'more than six times a year'.

[6] Answer categories ranged from 1: '(almost) never' to 4: '(almost) every day'.

[7] Answer categories ranged from 1: 'definitely not' to 3: 'Yes, definitely'.

[8] We have replaced an item in the original scale about the usefulness of writing public officials by the first item listed because the former seemed to tap mainly into political cynicism.

[9] Since the items for ethnic deservingness did not contain don't know answers we could not use them in this measure.

[10] If cultural insecurity is removed from the analysis explaining welfare universalism, education has a small but significant effect and the impact of cultural participation increases. The fact that cultural insecurity suppressed the education effect indicates this effect should be interpreted as a cultural one. 


\section{References}

Achterberg, P. (2006a) Considering Cultural Conflict. Class Politics and Cultural Politics in Western Societies. Maastricht: Shaker Publishing.

Achterberg, P. (2006b) 'Class Voting in the New Political Culture: Economic, Cultural and Environmental Voting in 20 Western Countries', International Sociology 21 (2): 237-62. Achterberg, P. and Houtman, D. (2006) 'Why Do So Many People Vote 'Unnaturally'? A Cultural Explanation for Voting Behavior', European Journal of Political Research 45 (1): 75-92.

Achterberg, P. and Houtman, D. (2009) 'Ideologically 'Illogical'? Why Do the LowerEducated Dutch Display so Little Value Coherence?', Social Forces 87(3): 1649-70. Alford, R.R. (1967) 'Class Voting in the Anglo-American Political Systems', in S.M. Lipset and S. Rokkan (eds) Party Systems and Voter Alignments: Cross-National Perspectives. New York: Free Press.

Applebaum, L. (2002) 'Who deserves Help/ Opinions About the Deservingness of Different Groups Living in Germany to Receive Aid', Social Justice Research 15 (3): 201-25. Bay, A-H and Pedersen, A. (2006) 'The Limits of Social Solidarity: Basic Income, Immigration and the Legitimacy of the Universal Welfare State', Acta Sociologica 49 (4): 419-36.

Bell, D. (1976) The Cultural Contradictions of Capitalism. New York: Basic Books.

Blank, T. (2003) 'Determinants of National Identity in East and West Germany: An Empirical Comparison of Theories on the Significance of Authoritarianism, Anomie, and General Self-Esteem', Political Psychology 24 (2): 259-88. 
Bobo, L. and Licari, F.C. (1989) 'Education and Political Tolerance: Testing the Effects of Cognitive Sophistication and Target Group Affect', Public Opinion Quarterly 53 (2): 285-308.

Bourdieu, P. (1984) Distinction: A Social Critique of the Judgement of Taste. London Routledge.

Bourdieu, P. (1986) 'The Forms of Capital', in J. G. Richardson (ed.) Handbook of Theory and Research for the Sociology of Education. New York: Greenwood Press.

Budge, I. (2000) 'Expert Judgements of Party Policy Positions: Uses and Limitations in Political Research', European Journal of Political Research 37 (1): 103-13.

Campbell, A., Converse, P.E., Miller, W.E. and Stokes, D.E. (1960) The American Voter. New York / London / Sydney: John Wiley and Sons, Inc.

Carmines, E.G. and Stimson, J.A. (1982) 'Racial Issues and the Structure of Mass Belief Systems', The Journal of Politics 44 (1): 2-20.

Clark, T.N. (1996) 'Structural Realignments in American City Politics. Less Class, More Race, and a New Political Culture', Urban Affairs Review 31 (6): 367-403.

Clark, T.N. and Lipset, S.M. (1991) ‘Are Social Classes Dying?’, International Sociology 6 (4): 397-410.

Coenders, M. (2001) Nationalistic Attitudes and Ethnic Exclusionism in a Comparative Perspective. Nijmegen: ICS/KUN.

Converse, P.E. (1964) 'The Nature of Belief Systems in Mass Publics' in D.E. Apter (ed.) Ideology and Discontent, International Yearbook of Political Behavior Research, Volume 5. New York: Free Press.

De Koster, W., Van der Waal, J., Achterberg, P. and Houtman, D. (2008) 'The Rise of the Penal State. Neo-Liberalization or New Political Culture', British Journal of Criminology 48 (6): 720-34. 
De Witte, H. (1997) 'De ideologische cultuur van arbeiders in Vlaanderen. Een replicatie en uitbreiding op basis van de IPSO-data, Tijdschrift voor Sociologie 18 (1-2): 53-78.

Derks, A. (2006) 'Populism and the Ambivalence of Egalitarianism. How Do the Underprivileged Reconcile a Right Wing Party Preference with Their Socio-Economic Attitudes?', World Political Science Review 2 (3): article 1.

DiMaggio, P. (1982) 'Cultural Capital and School Success: The Impact of Status Culture Participation on the Grades of U.S. High School Students', American Sociological Review 47 (2): 189-201.

DiMaggio, P. and Mohr, J. (1985) 'Cultural Capital, Educational Attainment, and Marital Selection', American Journal of Sociology 90 (6): 1231-61.

Dumais, S. A. (2002) 'Cultural Capital, Gender, and School Success: The Role of Habitus', Sociology of Education 75 (1): 44-68.

Eitle, T. M. and Eitle, D. J. (2002) 'Race, Cultural Capital, and the Educational Effects of Participation in Sports', Sociology of Education 75 (2): 123-46.

Eisinga, R. and Scheepers, P. (1989) Etnocentrisme in Nederland: Theoretische en empirische verkenningen. Nijmegen: ITS.

Elchardus, M. and Smits, W. (2002) Anatomie en oorzaken van het wantrouwen. Brussel: VUBPRESS.

Emler, N. and Frazer, E. (1999) 'Politics: The Education Effect', Oxford Review of Education 25 (1-2): 251-73.

Farnen, R.F. and Meloen, J.D. (2000) Democracy, Authoritarianism and Education: A CrossNational Empirical Survey. Basingstoke: Palgrave Macmillan.

Federico, C. (2005) 'Racial Perceptions and Evaluative Responses to Welfare: Does Education Attenuate Race-of-Target Effects?', Political Psychology 26 (5): 683-98. 
Fiske, S.T. and Kinder, D.R. (1981) 'Involvement, Expertise, and Schema Use: Evidence from Political Cognition' in N. Cantor and J. Kihlstrom (eds) Personality, Social Cognition, and Social Interaction. Hillsdale, N.J.: Erlbaum.

Fleishman, J.A. (1988) 'Attitude Organization in the General Public: Evidence for a Bidimensional Structure', Social Forces 67 (1): 159-84.

Gilens, M. (1995) 'Racial Attitudes and Opposition to Welfare', The Journal of Politics 57 (4): 994-1014.

Hechter, M. (2004) 'From Class to Culture', American Journal of Sociology 110 (2): 400-45.

Houtman, D. (2001) 'Class, Culture and Conservatism. Reassessing Education as a Variable in Political Sociology' in T.N. Clark and S.M. Lipset (eds) The Breakdown of Class Politics. A Debate on Post-Industrial Stratification. Washington D.C.: Woodrow Wilson Center Press.

Houtman, D. (2003) Class and Politics in Contemporary Social Science. "Marxism Lite" and its Blind Spot for Culture. New York: Aldine de Gruyter.

Houtman, D., Achterberg, P. and Derks, A. (2008) Farewell to the Leftist Working Class. New Brunswick, N.J.: Transaction.

Hyman, H.H. and Wright, C.R. (1979) Education's Lasting Effect on Values. Chicago: The University of Chicago Press.

Inglehart, R. (1997) Modernization and Postmodernization: Cultural, Economic, and Political Change in 43 Societies. Princeton, New Jersey: Princeton University Press. Jackson, T.H. and Marcus, G.E. (1975) 'Political Competence and Ideological Constraint', Social Science Research 4 (1): 93-111.

Jensen, R. (1995) 'The Culture Wars, 1965-1995: A Historian’s Map', Journal of Social History 29 (October): 17-37. 
Jenssen, A.T. and Engesbak, H. (1994) 'The Many Faces of Education: Why are People with Lower Education More Hostile Towards Immigrants than People with Higher Education?', Scandinavian Journal of Educational Research 38 (1): 33-50.

Judd, C. and Krosnick, J. (1989) 'The Structural Bases of Consistency among Political Attitudes: Effects of Political Expertise and Attitude Importance' in A.R. Pratkanis, J. Beckler and G. F. Greenwald (eds) Attitude Structure and Function. Hillsdale, N.J.: Erlbaum.

Katsillis, J. and Rubinson, R. (1990) 'Cultural Capital, Student Achievement, and Educational Reproduction: The Case of Greece', American Sociological Review 55 (2): 270-79. Kitschelt, H.P. (1995) The Radical Right in Western Europe: A Comparative Analysis. Ann Arbor: University of Michigan Press.

Lamont, M. (1987) 'Cultural Capital and the Liberal Political Attitudes of Professionals: Comment on Brint', American Journal of Sociology 92 (6): 1501-06.

Lerner, R., Nagai, A.K. and Rothman, S. (1991) 'Elite vs. Mass Opinion: Another Look at a Classic Relationship', International Journal of Public Opinion Research 3 (1): 1-31. Lipset, S.M. (1981) Political Man. The Social Bases of Politics, 2nd ed., Baltimore: The John Hopkins University Press.

Lutterman, K.G. and Middleton, R. (1970) ‘Authoritarianism, Anomia, and Prejudice’, Social Forces 48 (3): 485-92.

Marshall, G., Newby, H., Rose, D. and Vogler, C. (1988) Social Class in Modern Britain. London: Hutchinson.

Mau, S. and Burkhardt, C. (2009) 'Migration and Welfare State Solidarity in Western Europe', Journal of European Social Policy 19 (3): 213-29.

McDill, E.L. (1961) ‘Anomie, Authoritarianism, Prejudice, and Socio-Economic status: An Attempt at Clarification', Social Forces 39 (3): 239-45. 
Middendorp, C.P. (1991) Ideology in Dutch Politics, The Democratic System Reconsidered 1970 - 1985. Assen: Van Gorcum.

Mudde, C. (2000) The Ideology of the Extreme Right. Manchester: Manchester University Press.

Nisbet, M.C. (2005) 'The Competition for Worldviews: Values, Information, and Public Support for Stem Cell Research', International Journal of Public Opinion Research 17 (1): $90-112$.

Olzak, S. (1992) The Dynamics of Ethnic Competition and Conflict. Stanford: Stanford University Press.

Roberts, A.H. and Rokeach, M. (1956) 'Anomie, Authoritarianism, and Prejudice: A Replication', American Journal of Sociology 61 (3): 355-58.

Scheepers, P., Gijsberts, M. and M. Coenders (2002) 'Ethnic Exclusionism in European Countries', European Sociological Review 18 (1): 17-34.

Simpson, M. (1972) ‘Authoritarianism and Education: A Comparative Approach’, Sociometry 35 (2): $223-34$.

Srole, L. (1956) 'Social Integration and Certain Corollaries: An Exploratory Study', American Sociological Review 21 (6): 709-16.

Stubager, R. (2008) 'Education Effects on Authoritarian-Libertarian Values: A Question of Socialization', British Journal of Sociology 59 (2): 327-50.

Stubager, R. (2009) 'Education-Based Group Identity and Consciousness in the AuthoritarianLibertarian Value Conflict', European Journal of Political Research 48 (2): 204-33.

Svallfors, S. (1991) 'The Politics of Welfare Policy in Sweden: Structural Determinants and Attitudinal Cleavages', British Journal of Sociology 42 (4): 609-34. 
Svallfors, S. (2007) 'Class and Attitudes to Market Inequality: A comparison of Sweden, Britain, Germany and the United States' in S. Svallfors (ed.) The Political Sociology of the Welfare State. Stanford: Stanford University Press.

Van der Waal, J. (2009a) 'De invloed van immigratie op de lonen in Amsterdam en Rotterdam. De substitutiethese getoetst in twee stedelijke contexten', Sociologie 5 (1): 89-111.

Van der Waal, J. (2009b) 'The Conditionality of the Substitution Thesis on Type of Urban Economy. An Analysis on the Impact of Immigration on Unemployment in Dutch Metropolitan Areas', The Erasmus University Working Paper Series on Sociology 3. Van der Waal, J. (2010) Unravelling the Global City Debate. Economic Inequality and Ethnocentrism in Contemporary Dutch Cities. Doctoral Dissertation, Erasmus University Rotterdam.

Van der Waal, J. and Achterberg, P. (2006) 'Stille revolutie, contra-revolutie of cultureel conflict? Veranderingen in de politieke cultuur en hun invloed op het klassengebonden stemgedrag', Res Publica 46 (4): 369-92.

Van der Waal, J., Achterberg, P. and Houtman, D. (2007) 'Class Is Not Dead - It Has Been Buried Alive: Class Voting and Cultural Voting in Postwar Western Societies (19561990)', Politics and Society 35 (3): 403-26.

Van Oorschot, W. (2000) 'Who Should Get What, and Why? On Deservingness Criteria and the Conditionality of Solidarity among the Public', Policy and Politics 28 (1): 33-48.

Van Oorschot, W. (2006) 'Making the Difference in Social Europe: Deservingness Perceptions among Citizens of European Welfare States', Journal of European Social Policy 16 (1): 23-42.

Van Oorschot, W. (2007) 'Solidarity Towards Immigrants in European Welfare States', International Journal of Social Welfare 17 (1): 3-14. 
Van Oorschot, W. and Uunk, W. (2007) 'Welfare Spending and the Public's Concern for Immigrants', Comparative Politics 40 (1): 63-86.

Weil, F.D. (1985) 'The Variable Effects of Education on Liberal Attitudes: A Comparative Historical Analysis of Anti-Semitism Using Public Opinion Survey Data', American Sociological Review 50 (4): 458-74.

Wilson, B. (1982) Religion in Sociological Perspective. Oxford: Oxford University Press. Wright, E.O. (1985) Classes. London: Verso.

Zaller, J.R. (1992) The Nature and Origins of Mass Opinion. Cambridge, NY: Cambridge University Press. 